\title{
The Effect of Using Different Detergents in Cleaning Cows' Udders on The Microbial Content of Produced Milk
}

\author{
Nizar Issa Alrabadi ${ }^{1} \&$ Kamel I. Sultan ${ }^{2}$ \\ ${ }^{1}$ Department of Food Science and Nutrition, Faculty of Agriculture, Jerash University, Jordan \\ ${ }^{2}$ Department of Agricultural Economics and Extension, Faculty of Agriculture, Jerash University, Jerash, Jordan \\ Correspondence: Nizar Issa Alrabadi, Department of Food Science and Nutrition, Faculty of Agriculture, Jerash \\ University, Jordan. Email: rabadinizar@yahoo.com
}

Received: April 15, 2018

doi:10.5539/ijb.v10n3p47
Accepted: May 17, 2018

Online Published: June 15, 2018

\begin{abstract}
This study investigated the effect of different detergents used to clean cows' udders on the microbial content of the produced milk using twenty cows in Ajloun, a northern city in Jordan. The milking process was repeated from same cows on three successive days. On day 1, we milked the cows after cleaning their udders using water only. This was repeated on the two successive days. Thereafter, the cows were milked after cleaning their udders by a different detergent each day. The process was also repeated for three successive days for each detergent. Microbial Analysis was carried out on the collected milk samples. The results indicated that cleaning cows' udders before milking has improved the hygiene conditions and reduced the total bacterial count, total coliform, staphylococci and enterococci spp counts and the values of yeast and molds. Different detergents had different effects on the microbial counts. Finally, the effectiveness of the detergent differed according to its brand. Our findings are important to public health because milk has been a traditional food and ironically a very potent carrier of gastrointestinal infections, if contaminated.
\end{abstract}

Keywords: Milk, Detergents, Microbial Analysis, Cows, Udders, Jordan

\section{Introduction}

Milk is one of the most essential foods to human beings; it is rich in nutrients vital for growth and maintenance of a healthy body (Vilela, 2002). It is an emulsion or colloid of butterfat globules within a water-based fluid that contains dissolved carbohydrates and protein aggregates with minerals (Jost, 2007). It is rich in proteins, fats, carbohydrates (lactose), mineral salts, vitamins, conjugated linoleic acid, sphingomyelin, butyric acid, among other substances, which provide immunologic protection and essential nutrients to its consumers (Sordillo et al., 1997; Oliveira et al., 1999). A variety of dairy products are produced from milk, such as cream, butter, yogurt, ice cream, and cheese. Modern industrial processes use milk to produce casein, whey protein, lactose, condensed milk, powdered milk, and many other food-additives and industrial products.

Nevertheless, milk is vulnerable to contamination by many microorganisms including pathogenic microbes, which can cause the food-borne illness and are a threat to consumer's health. Thus, it has no protection from external contamination and can be contaminated easily when it is separated from the source animals like cows or buffaloes (Agarwal, 2012). Moreover, milk is a suitable medium for most bacteria because of its chemical characteristics such as high water content, approximate neutral $\mathrm{pH}$ value and its nutrient contents.

Contamination of milk could occur at any stage of production starting from the circumstances surrounding the milking process to the delivery of the final product. The level of contamination is influenced by several factors such as, animal health and nutrition, housing and feeding facilities, parlor design, milking procedures, herd management techniques, herd size and milk yield (Bramley et al., 1992; Sanaa et al., 1993; Ko"ster et al., 2006). This study focused on the contamination that may occur during the milking process. Different premilking cleaning regimes have been studied previously (Galton et al., 1984, 1986; Pankey 1989, Gibson et al., 2005, 2008). however, as far as the author knowledge, there are no recommendations for the proper pre-milking treatment to reduce microbial load. 
This study evaluated the microbial content of raw milk before and after using different detergents used to clean cows' udders in Jordan. The remaining of the study is organized as follows: Section 2 describes materials and methods, Section 3 shows results, Section 4 is a discussion and Section 5 concludes.

\section{Material and Method}

\subsection{Samples Collection}

This study was conducted in Ajloun, a northern city in Jordan. Twenty healthy cows were selected from a cow farm. The milk was collected from same cows on a daily basis but in different conditions. Six treatments were conducted and each treatment was repeated three times on three successive days. The first treatment (control sample) included milking the cows after cleaning their udders with water only. The other five treatments included milking cows after cleaning their udders by a different liquid hand wash detergent for each treatment. The detergents used were Gersy (detergent 1), Al Emlaq (detergent 2), Dove (detergent 3), Pass (detergent 4) and Hygiene (detergent 5). The samples were moved from the farm to the lab in a cooled box. Thereafter, a microbial analysis was carried out on the collected milk samples.

The milking process was conducted automatically using a milking machine. In order to minimize the chances of any contamination, the following milking steps were applied:

1) Milker preparation: The hands of a person milking cows can become contaminated, so that the milker was wearing latex gloves which were replaced periodically through the milking process.

2) Cleaning the udders: The udders were prepared by thoroughly cleaning them and the teats either with water (control sample) or with a certain detergent.

3) Drying the udders: The udders were dried thoroughly using a separate dry towel (a sterilized cloth).

4) Application of the machine: The milking machine was applied within one minute of the initial wiping of the teats to take maximum advantage of the milk letdown response.

5) Detaching the machine at the end of milking: The vacuum was turned off before the machine was removed.

6) The milking machine and the milk utensils were sterilized over time.

\subsection{Microbial Analysis}

Before platting the samples, they were diluted by adding $1 \mathrm{ml}$ of each milk sample into sterile test tube having 9 $\mathrm{ml}$ peptone water. After thoroughly mixing, the sample was serially diluted up to $1: 10^{-7}$. Thereafter, the samples were platted on selective media and incubated at the appropriate temperatures. The total bacterial counts were enumerated on Nutrient agar (NA) (Difco); plates were incubated for $48 \mathrm{~h}$ at $32^{\circ} \mathrm{C}$, (Difco, 1984). The total coliform bacteria were counted on the MacConkey agar medium (Difco); plates were incubated at $37^{\circ} \mathrm{C}$ for $48 \mathrm{~h}$. The MSA (manitol salt agar) medium (Biolife) were used to enumerate the total staphylococci; plates were incubated at $37^{\circ} \mathrm{C}$ for $48 \mathrm{~h}$. Enterococci spp. were counted using BEA (bile esculin agar) medium (Difco); plates were incubated at $37^{\circ} \mathrm{C}$ for $48 \mathrm{~h}$. Finally, yeast and molds were enumerated on potato dextrose agar (acidified) medium, plates were incubated at $25^{\circ} \mathrm{C}$ for 7 days.

\subsection{Statistical Analysis}

Statistical analysis was performed using the Statistical Package for the Social Sciences (SPSS, Version 21). Analysis of Variance (ANOVA) was used to examine the differences among samples. Moreover, a Post Hoc analysis was performed using LSD test to compare means differences at a significance probability rate of 0.05 ( $\mathrm{P}$ $\leq 0.05$ ).

\section{Results}

Table 1 shows the following results:

Total Bacterial Count: There was a highly significant effect $(\mathrm{P} \leq 0.01)$ of the different detergents on total bacterial count. When comparing the means, we notice that all the detergents total bacterial count means showed significant differences $(\mathrm{P} \leq 0.05)$. There was a significant reduction $(\mathrm{P} \leq 0.01)$ in total bacterial count by detergentl as the total bacterial count value was reduced from $6.53 \log \mathrm{cfu} / \mathrm{ml}$ for the control to $4.36 \mathrm{log} \mathrm{cfu} / \mathrm{ml}$ for detergent 1 . The highest reduction in total bacterial count was by detergent 5 where the value dropped to 4.04 $\log \mathrm{cfu} / \mathrm{ml}$.

Total Coliform: There was a highly significant effect $(\mathrm{P} \leq 0.01)$ of the different detergents on the total coliform. There was a significant difference $(\mathrm{P} \leq 0.05)$ among the means of different values of total coliform, except the means for detergents 2 and 3 and also for detergents 4 and 5 where there were no significant differences among 
the means. The total coliform values dropped in all detergents as compared to the control sample. The highest reduction in total coliform was by detergent 5 .

Staphylococci: The results of staphylococci showed a highly significant $(\mathrm{P} \leq 0.01)$ reduction in its values as a result of using different detergents. There were no significant differences $(P \leq 0.05)$ among the means for detergents 1, 2, 3 and $4(\mathrm{P}>0.05)$. However, the values of staphylococci were reduced comparing to the control sample as a result of using different detergents, for example, the staphylococci value was reduced from $2.04 \log$ $\mathrm{cfu} / \mathrm{ml}$ for the control to $1.3 \mathrm{log} \mathrm{cfu} / \mathrm{ml}$ for detergent 1 . The highest reduction in staphylococci occurred as a result of using detergent 5 where the value decreased to $0.7 \log \mathrm{cfu} / \mathrm{ml}$.

Enterococci spp.: There was a highly significant effect $(\mathrm{P} \leq 0.01)$ on enterococci spp. values as a result of the different detergents. When comparing the means, there was a significant difference $(\mathrm{P} \leq 0.05)$ among the means. The lowest value of enterococci spp. occurred as a result of detergent 5 where it was reduced to 1.00 .

Yeast and Mold: There was a highly significant effect $(\mathrm{P} \leq 0.01)$ of the detergents on yeast and mold, where they were reduced from $2.77 \mathrm{log} \mathrm{cfu} / \mathrm{ml}$ for the control sample to $2.63 \mathrm{log} \mathrm{cfu} / \mathrm{ml}$ for detergent 1 . There was a significant difference among the means except for the detergents 3 and 5 where there was no significant difference $(\mathrm{P}>0.05)$. The lowest value was for the fifth detergent where yeast and mold value was reduced to $2.01 \log$ $\mathrm{cfu} / \mathrm{ml}$.

Table 1 . The results of microbial analysis $(\log \mathrm{cfu} / \mathrm{ml})$

\begin{tabular}{crrrrr}
\hline Treatment & $\begin{array}{c}\text { Total Bacterial Count } \\
\pm \text { SEM }^{*}\end{array}$ & $\begin{array}{c}\text { Total Coliform } \\
\pm \text { SEM }\end{array}$ & $\begin{array}{c}\text { Staphylococci } \\
\pm \text { SEM }\end{array}$ & $\begin{array}{c}\text { Enterococci.spp } \\
\pm \text { SEM }\end{array}$ & $\begin{array}{c}\text { Yeast and Mold } \\
\pm \text { SEM }\end{array}$ \\
\hline control & $6.53 \mathrm{a}^{* *} \pm 0.325$ & $4.68 \mathrm{a} \pm 0.012$ & $2.04 \mathrm{a} \pm 0.003$ & $2.34 \mathrm{a} \pm 0.017$ & $2.77 \mathrm{a} \pm 0.040$ \\
Detergent 1 & $4.36 \mathrm{~b} \pm 0.035$ & $2.04 \mathrm{~b} \pm 0.017$ & $1.30 \mathrm{~b} \pm 0.029$ & $1.04 \mathrm{~b} \pm 0.023$ & $2.63 \mathrm{~b} \pm 0.000$ \\
Detergent 2 & $4.53 \mathrm{c} \pm 0.017$ & $1.40 \mathrm{c} \pm 0.023$ & $1.28 \mathrm{bc} \pm 0.035$ & $1.36 \mathrm{c} \pm 0.035$ & $2.51 \mathrm{c} \pm 0.017$ \\
Detergent 3 & $4.28 \mathrm{~d} \pm 0.023$ & $1.34 \mathrm{~cd} \pm 0.023$ & $1.25 \mathrm{bcd} \pm 0.006$ & $1.11 \mathrm{~d} \pm 0.120$ & $2.08 \mathrm{~d} \pm 0.046$ \\
Detergent 4 & $4.61 \mathrm{e} \pm 0.023$ & $1.18 \mathrm{e} \pm 0.035$ & $1.38 \mathrm{bcde} \pm 0.012$ & $1.40 \mathrm{e} \pm 0.052$ & $2.42 \mathrm{e} \pm 0.006$ \\
Detergent 5 & $4.04 \mathrm{f} \pm 0.017$ & $1.15 \mathrm{ef} \pm 0.040$ & $0.70 \mathrm{f} \pm 0.310$ & $1.00 \mathrm{f} \pm 0.000$ & $2.01 \mathrm{df} \pm 0.006$ \\
Significance & HS & HS & HS & HS \\
\hline
\end{tabular}

* SEM is the standard error of the means

** Values having different letters in the same column are significantly different $(\mathrm{P} \leq 0.05)$.

$* * * \mathrm{HS}=$ highly significant difference $(\mathrm{P} \leq 0.01)$.

\section{Discussion}

Numerous studies have focused on the microbial content of milk. Marcondes et al. (2014) evaluated the quality of raw milk in different production systems and its variation throughout the year. Their data were collected from 943 dairy farms in Brazil. They found that total bacterial count was affected by production, thus confinement systems present a better total bacterial count content. Both month and year are factors that interfere with the total bacterial count and the best patterns were found in the coldest periods of the year. Mišeikienè et al. (2015) investigated the influence of pre-milking teat antiseptic solutions on total bacterial contamination of teat skin. Three udder antiseptics were applied: Dermisan $0.5 \%$ (active ingredient -aminopropyl laurylamine), $0.2 \%$ solution with active ingredient iodine, and foaming solution of natural compounds (lactic acid + glycerol+allantoin). Cow teats were swabbed before and after application of udder preparations. The total bacterial contamination on cows teat skin was determined employing serial dilutions and plate count method. The results showed that the udder applications with lactic acid and iodine had the highest probability of reducing total bacterial contamination. The use of udder antiseptics for premilking teats preparation reduced the levels of coliforms, coagulase negative staphylococci and Streptococcus uberis but with exception of iodine, no effect was found on reducing Candida genus yeasts. Agarwal et al. (2012) evaluated the effect of household practices on the microbiological profile of milk. Milk samples of pasteurized, ultra heat treated (UHT) as well as unpasteurized milk (Vendor's milk) were collected. The effect of different storage practices and treatments on the microbiological profile (standard plate count (SPC), coliform, E. coli, Salmonella, Shigella, Staphylococcus aureus, yeast and moulds, anaerobic spore count, and Listeria monocytogenes) of milk was studied using 
National/ International Standard Test Methods. The results indicated that average SPC in vendor's milk was found very high as compared to pasteurized milk. Coliform, yeast and moulds, E. coli, and Staphylococcus aureus were detected in the samples of vendor's as well as pasteurized milk. Boiling the milk reduces SPC and kills the other microorganisms. Storage of boiled milk under room temperature or refrigerated condition resulted in a similar increase in SPC at the end of $24 \mathrm{~h}$, but storage of un-boiled milk even under refrigerated conditions increased SPC manifold after $24 \mathrm{~h}$. Gibson et al. (2008) studied the effectiveness of premilking teat-cleaning regimes in reducing the teat microbial load and effect on milk quality. The effectiveness of several premilking teat-cleaning regimes in reducing teat microbial load was assessed using 40 cows on each of the four commercial UK dairy farms with herringbone parlours during two sampling periods. The cleaning regimes included dry wipe, Alcohol-based medi-wipe, Iodine-based dip and dry and Hypochlorite wash and dry. The results showed that all of the cleaning techniques studied reduced teat microbial load, however, the chlorine wash and dry was the most effective. Anderson et al. (2011) investigated the presence and levels of microbes in unexpired pasteurized milk from randomly selected supermarkets in Kingston, Jamaica. They collected 20 representative milk samples from six (6) supermarkets. Microbiological tests such as methylene blue reduction, standard plate count (SPC), coliform plate count (CPC), purity plate culture, gram staining and biochemical tests were performed. They found unacceptable levels of Enterobacter spp. and Escherichia coli in most of the samples. To the best of author's knowledge, this is the first study in Jordan that investigated the effect of using different detergents in cleaning cows' udders on the microbial content of produced milk. Our findings indicated that using detergents significantly reduces the counts of the examined bacteria and the values of yeast and molds. Moreover, There were significant differences in the results of different detergents, thus, which type of detergent to use is important to have a more healthy milk.

\section{Conclusion}

The efficacy of using five different detergents to clean cows' udders before milking on the microbial content of milk was investigated. Using samples from twenty cows in Jordan and based on microbial analysis, the results showed that cleaning cows' udders by detergents before milking significantly reduces the total bacterial count, total coliform, staphylococci and enterococci spp counts and the values of yeast and molds. Moreover, there were significant differences in the results of using different detergents. Thus, some detergents were more effective than others in reducing the microbial counts.

\section{References}

Agarwal, A., Awasthi, V., Dua, A., Ganguly, S., Garg, V., \& Marwaha, S. S. (2012). Microbiological profile of milk: Impact of household practices. Indian journal of public health, 56(1), 88-94. https://doi.org/10.4103/ 0019-557X.96984.

Anderson, M., Hinds, P., Hurditt, S., Miller, P., McGrowder, D., \& Alexander-Lindo, R. (2011). The microbial content of unexpired pasteurized milk from selected supermarkets in a developing country. Asian Pacific journal of tropical biomedicine, 1(3), 205-211. https://doi.org/10.1016/S2221-1691(11)60028-2

Bramley, A. J., Dodd, F. H., Mein, G. A., \& Bramley, J. A. (1992). Machine Milking and Lactation. Berks, UK: Insight Books.

Galton, D. M., Petersson, L. G., \& Merrill, W. G. (1986). Effects of premilking udder preparation practices on bacterial counts in milk and on teats. Journal of dairy science, 69(1), 260-266. https://doi.org/10.3168/jds.S0022-0302(86)80396-4.

Galton, D. M., Petersson, L. G., Merrill, W. G., Bandler, D. K., \& Shuster, D. E. (1984). Effects of premilking udder preparation on bacterial population, sediment, and iodine residue in milk. Journal of dairy science, 67(11), 2580-2589. https://doi.org/10.3168/jds.S0022-0302(84)81616-1

Gibson, H., Protheroe, R. G., Sinclair, L. A., Brizuela, C. M., \& Worton, H. (2005). Investigation of the Effectiveness of Pre-Milking Teat Cleaning Regimes. Final Report on Food Standards Agency Project Code B, 12003. https://onlinelibrary.wiley.com/doi/full/10.1111/j.1472-765X.2007.02308.x

Gibson, H., Sinclair, L. A., Brizuela, C. M., Worton, H. L., \& Protheroe, R. G. (2008). Effectiveness of selected premilking teat-cleaning regimes in reducing teat microbial load on commercial dairy farms. Letters in applied microbiology, 46(3), 295-300. https://doi.org/10.1111/j.1472-765X.2007.02308.x

Jost, R. (2007). Milk and Dairy Products. In W. Weinheim (Ed.), Ullmann's Encyclopedia of Industrial Chemestry (7th ed.). GmbH, Weinheim: Wiley-VCH Verlag. 
Köster, G., Tenhagen, B. A., \& Heuwieser, W. (2006). Factors associated with high milk test day somatic cell counts in large dairy herds in Brandenburg. I: Housing conditions. Transboundary and Emerging Diseases, 53(3), 134-139. https://doi.org/10.1111/j.1439-0442.2006.00814.x

Manual, D. (1984). Manual of Dehydrated Culture and Reagents for Microbiology Detroit. Michigan, Michigan, USA. https://doi.org/10.5962/bhl.title.7276

Marcondes, M. I., Jácome, D. C., Silva, A. L. D., Rennó, L. N., \& Pires, A. C. D. S. (2014). Evaluation of raw milk quality in different production systems and periods of the year. Revista Brasileira de Zootecnia, 43(12), 670-676. http://dx.doi.org/10.1590/S1516-35982014001200007

Mišeikienè, R., Rudejevienè, J., \& Gerulis, G. (2015). Effect of pre-milking antiseptic treatment on the bacterial contamination of cow teats skin. Bulgarian Journal of Veterinary Medicine, 18(2), 159-166. https://doi.org/10.15547/bjvm.833

Oliveira, C. A. F. D., Fonseca, L. F. L. D., \& Germano, P. M. L. (1999). Aspectos relacionados à produçäo, que influenciam a qualidade do leite. Hig. aliment, 13(62), 10-13. Retrieved from http://cienciadoleite.com.br/ noticia/2853/aspectos-relacionados-a-producao-que-influenciam-a-qualidade-do-leite.

Pankey, J. W. (1989). Premilking udder hygiene. Journal of dairy science, 72(5), 1308-1312. https://doi.org/10.3168/jds.S0022-0302(89)79238-9.

Sanaa, M., Poutrel, B., Menard, J. L., \& Serieys, F. (1993). Risk factors associated with contamination of raw milk by Listeria monocytogenes in dairy farms. Journal of Dairy Science, 76(10), 2891-2898. https://doi.org/10.3168/jds.S0022-0302(93)77628-6

Sordillo, L. M., Shafer-Weaver, K., \& DeRosa, D. (1997). Immunobiology of the mammary gland. Journal of dairy science, 80(8), 1851-1865. https://doi.org/10.3168/jds.S0022-0302(97)76121-6

Vilela, D. (2002). An importância econômica, social e nutricional do leite. Revista Batavo, 3, 17-18.

\section{Copyrights}

Copyright for this article is retained by the author(s), with first publication rights granted to the journal.

This is an open-access article distributed under the terms and conditions of the Creative Commons Attribution license (http://creativecommons.org/licenses/by/4.0/). 